\title{
Hydrography in the Mediterranean Sea during a cruise with RV Poseidon in April 2014
}

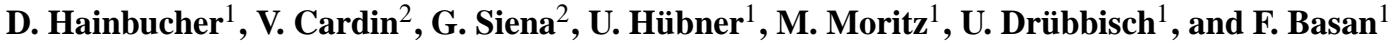 \\ ${ }^{1}$ Institut für Meereskunde, CEN, University of Hamburg, Bundesstraße 53, 20146 Hamburg, Germany \\ ${ }^{2}$ Istituto Nazionale di Oceanografia e di Geofisica Sperimentale - OGS, Dept. Of Oceanography, \\ Borgo Grotta Gigante 42/c, 34010 Sgonico, Trieste, Italy \\ Correspondence to: D. Hainbucher (dagmar.hainbucher@zmaw.de)
}

Received: 6 March 2015 - Published in Earth Syst. Sci. Data Discuss.: 13 May 2015

Revised: 11 August 2015 - Accepted: 20 August 2015 - Published: 3 September 2015

\begin{abstract}
We report on data from an oceanographic cruise in the Mediterranean Sea on the German research vessel Poseidon in April 2014. Data were taken on a west-east section, starting at the Strait of Gibraltar and ending south-east of Crete, as well on sections in the Ionian and Adriatic Sea. The objectives of the cruise were threefold: to contribute to the investigation of the spatial evolution of the Levantine Intermediate Water (LIW) properties and of the deep water masses in the eastern Mediterranean Sea, and to investigate the mesoscale variability of the upper water column. The measurements include salinity, temperature, oxygen and currents and were conducted with a conductivity, temperature and depth(CTD)/rosette system, an underway CTD and an acoustic Doppler current profiler (ADCP). The sections are on tracks which have been sampled during several other cruises, thus supporting the opportunity to investigate the long-term temporal development of the different variables. The use of an underway CTD made it possible to conduct measurements of temperature and salinity with a high horizontal spacing of $6 \mathrm{~nm}$ between stations and a vertical spacing of $1 \mathrm{dbar}$ for the upper $800 \mathrm{~m}$ of the water column.
\end{abstract}

\section{Data coverage and parameter measured}

Repository reference:

doi:10.1594/PANGAEA.838923 (for CTD)

doi:10.1594/PANGAEA.838924 (for UCTD)

doi:10.1594/PANGAEA.838934 (for ADCP)

Coverage: $34-43^{\circ} \mathrm{N}, 6^{\circ} \mathrm{W}-26^{\circ} \mathrm{E}$

Location name: the Mediterranean Sea

Date/time start: 3 April 2014

Date/time end: 28 April 2014

\section{Introduction}

The Mediterranean Sea is a marginal sea, as it is partly isolated from the Atlantic Ocean through the narrow Strait of Gibraltar. It consists of two sub-basins, the western (WMed) and the eastern (EMed) Mediterranean, which communicate through the broad $(145 \mathrm{~km})$ and shallow (maximum depth $550 \mathrm{~m}$ ) Sicily Channel. Due to its dimensions $\left(2500000 \mathrm{~km}^{2}\right)$ and position, i.e. enclosed by continents, it can rapidly be affected by atmospheric forcing and anthropogenic influences (Schroeder et al., 2013). Several forces drive the circulation - external ones like wind stress, strong topographic constraints and internal dynamic processes (Robinson et al., 2001; Pinardi et al., 2013). The emerging Mediterranean general circulation, therefore, encloses three predominant and interacting spatial scales: basin scale, sub-basin scale and mesoscale. Free and boundary currents and jets, permanent and recurrent, sub-basin-scale, cyclonic and anticyclonic gyres populate both basins (Robinson et al., 2001). The associated eddy field to the mesoscale circulation consists of semi-permanent eddies with a spatial scale of about $120 \mathrm{~km}$ in diameter (Hecht et al., 1988).

The WMed and EMed show distinct differences, both in their hydrography and circulation. Different attempts to schematize surface as well as intermediate and deep paths of the circulation have been made in the past, based on observational evidence (see e.g. Malanotte-Rizzoli et al., 1997, 
1999; Robinson et al., 2001; Roether et al., 2007; Schroeder et al., 2012).

The heat and freshwater budgets in the Mediterranean Sea are negative with a net loss of about $5 \mathrm{~W} \mathrm{~m}^{-2}$ and $0.7 \mathrm{~m} \mathrm{yr}^{-1}$. The deficits are balanced by exchanges through the Strait of Gibraltar. The steady state is balanced at multi-decadal timescales; at seasonal and interannual timescales heat loss and gain is possible due to single wintertime large evaporation events (Garrett et al., 1993; Pettenuzzo et al., 2010; Pinardi et al., 2013). However, it might be questionable if a steady state is a reliable assumption for the Mediterranean Sea circulation. As known, the EMed has been through drastic changes in the past. The largest climatic event, named Eastern Mediterranean Transient (EMT), took place in the EMed during the end of the 1980s and beginning of the 1990s, where the deep-water formation switched from the Adriatic to the Aegean Sea. This episode changed the thermohaline characteristics of the outflow through the Sicily Channel significantly, which consequently modified the characteristics of the WMed (Millot et al., 2006; Schroeder et al., 2006). Thus, since 2005 the deep waters of the WMed have experienced significant physical changes which are comparable to the EMT, both in terms of intensity and observed effects (Schroeder et al., 2008). This event is often called the Western Mediterranean Transient (WMT). Therefore, the existence of both transients contradicts this assumption. On the other hand, it was proven that the EMT had never been observed before (Roether et al., 2013).

The water mass formation cycle is characterized by the inflow of low-salinity Atlantic Water (AW) in the upper $100 \mathrm{~m}$ of the water column and with identification values of $S=36.0-36.5$ psu in the Strait of Gibraltar (Said et al., 2011), and a return flow of the salty Levantine Intermediate Water (LIW), formed in the Levantine Basin and positioned in the intermediate layer (typically at a depth of 200$600 \mathrm{~m}$ ). The depth variability of the LIW salinity maximum is largely regional; generally, depths increase westward. The Sicily Channel, with a depth lower than $550 \mathrm{~m}$, acts as a natural barrier between the WMed and EMed. Deep and intermediate water formation takes place in each of the basins. In the WMed, the abyssal water mass is produced by shelf and open-ocean convection in the Gulf of Lyons, namely the Western Mediterranean Deep Water (WMDW, see e.g. Leaman and Schott, 1991). The EMed is instead characterized by two deep-water formation regions, where the Adriatic Deep Water (AdDW) and the Cretan Deep Water (CDW) are produced. Thus, the predominant water mass of the bottom layers, filling the abyssal plains of the Ionian and Levantine basins, namely the Eastern Mediterranean Deep Water (EMDW), is a mixture of AdDW, CDW and shallower water masses. Detailed descriptions of the general circulation and hydrography of the EMed can be found in Lascaratos et al. (1999), Hamad et al. (2005), Rubino and Hainbucher (2007), Klein et al. (2010), Gačić et al. (2011), Cardin et al. (2015) and others.
The principal scientific objective of the cruise is threefold:

1. to add knowledge to the understanding of the dispersion of LIW water masses from the eastern basin of the Mediterranean Sea to the Strait of Gibraltar

2. to investigate the mesoscale variability of the upper water columns of the two basins of the Mediterranean Sea

3. to continue the documentation and to contribute to the understanding of the evolution of the deep water masses in the EMed since the appearance of the Eastern Mediterranean Transient.

According to the Med-Ship program (CIESM Monographs $43,2012)$ the cruise supports the investigation of its relevant objectives which are, amongst others, engaged in the determination of changes and of long-term variability of hydrographic parameters in the Mediterranean Sea. Although most of the data of this campaign are not "full water column observations", this survey is a valuable contribution to improve the database of the Mediterranean Sea for a better understanding of the variability on multiple timescales and for numerical model evaluations.

To our knowledge, just one further campaign exists which covers an east-west transect through the whole Mediterranean Sea, but with a much lower sampling rate (Meteor cruise M84-3, Tanhua et al., 2013). More frequently, several campaigns at the level of sub-basin for both the WMed (Schroeder et al., 2008) and the EMed (Cardin et al., 2015) have been carried out during the past decades.

\section{Data source}

The survey was carried out on the German RV Poseidon from 3 to 28 April 2014. The cruise started in Portimão, Portugal, and ended in Bari, Italy (Fig. 1). The data set is composed of three components: profiles from a conductivity, temperature and depth (CTD) system, profiles from an underway CTD (UCTD) and velocity profiles from an acoustic Doppler current profiler (ADCP) (Table 1). Figures 2, 3 and 4 show examples for the calibrated and quality-controlled data from the UCTD, CTD and ADCP.

\section{Methods and quality control}

The most recent campaign (April 2011), including an eastwest transect through the whole Mediterranean Sea, was the RV Meteor cruise M84/3 (Tanhua et al., 2013). On M84/3 $\mathrm{CTD}$ and ADCP measurements were conducted. In addition to the physical parameters, chemical variables like nutrients, helium, tritium, $\mathrm{SF}_{6}, \mathrm{CFC}-12$ and others were taken. Compared to the cruise in this paper, the sampling rate of M84-3 was coarse, accommodating the demand to take a variety of parameters during a reasonable time. Contrariwise, the campaign of Poseidon was restricted to measurements of physical 
Table 1. List of parameters from Poseidon cruise P468 as seen in the PANGAEA database. PI (Principal Investigator): Dagmar Hainbucher.

\begin{tabular}{|c|c|c|c|c|}
\hline Parameter name & Short name & Unit & Method & Comments \\
\hline DATE/TIME & Date/time & & & Geocode \\
\hline LATITUDE & Latitude & & & Geocode \\
\hline LONGITUDE & Longitude & & & \\
\hline Pressure, water & Press & dbar & CTD, SEA_BIRD SBE 911plus & \\
\hline Temperature, water & Temp & ${ }^{\circ} \mathrm{C}$ & CTD, SEA_BIRD SBE 911plus & \\
\hline Salinity & Sal & & CTD, SEA_BIRD SBE 911plus & PSU \\
\hline Oxygen & $\mathrm{O}_{2}$ & $\mu \mathrm{mol} \mathrm{L}{ }^{-1}$ & CTD calibrated with attached oxygen sensor, corrected using Winkler titration & \\
\hline Pressure, water & Press & dbar & Underway CTD (UCTD), Oceanscience & \\
\hline Temperature, water & Temp & ${ }^{\circ} \mathrm{C}$ & Underway CTD (UCTD), Oceanscience & \\
\hline Salinity & Sal & & Underway CTD (UCTD), Oceanscience & PSU \\
\hline DEPTH, water & Depth water & $\mathrm{m}$ & & Geocode \\
\hline Current velocity east-west & UC & $\mathrm{cm} \mathrm{s}^{-1}$ & Shipboard Acoustic Doppler Current Profiling (SADCP) & \\
\hline Current velocity north-south & $\mathrm{VC}$ & $\mathrm{cm} \mathrm{s}^{-1}$ & Shipboard Acoustic Doppler Current Profiling (SADCP) & \\
\hline
\end{tabular}

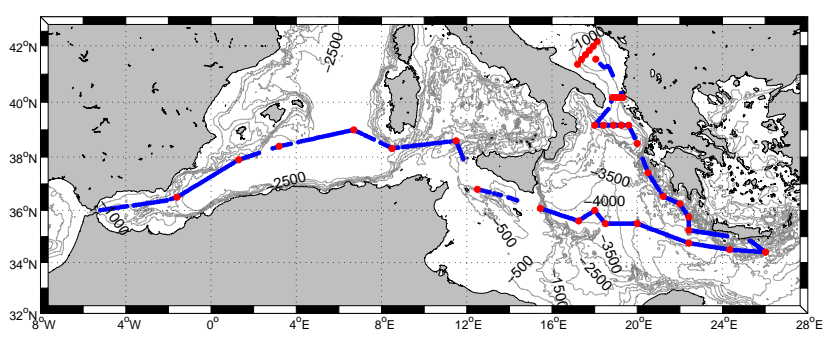

Figure 1. Cruise track of P468 with CTD stations marked in red and UCTD stations marked in blue.

components, but with the aim of achieving a high horizontal resolution in order to resolve hydrographic phenomena on mesoscales.

\subsection{CTD/rosette}

During the cruise, altogether 37 full depth standard hydrographic stations (Fig. 1) were collected with a $24 \mathrm{~Hz}$ sampling Sea-Bird SBE 911plus CTD, fastened to a 12bottle SBE 32 Carousel Water Sampler. The instrument was equipped with double conductivity and temperature sensors and two SBE 43 dissolved oxygen sensors. Specifications for the CTD sensors are given in Table 2.

At almost all stations water samples were taken at 12 predefined depths along the water column for oxygen analysis and three of which also for salinity analysis. The salinity samples were analysed on board using a Guildline Autosal Salinometer. The batch no. of the standard seawater samples is $38 \mathrm{H} 11$ and they have a K15-factor of $1.07631\left(24^{\circ} \mathrm{C}\right)$. An explanation of standard seawater definitions can be found in Bacon et al. (2007).

Temperature and salinity CTD data were post-processed by applying standard Seabird software and MATLAB routines. At this stage spikes were removed, 1 dbar averages were calculated and the downcast profiles of temperature and salinity were corrected with regression analysis. Data from
Table 2. CTD instrument and sensors used. Owners of instruments are either the University of Hamburg, Germany (IFM-CEN) or the National Institute of Oceanography and Geophysics (OGS), Italy.

\begin{tabular}{ll}
\hline Instrument/sensor & Serial number (owner) \\
\hline SBE 911plus/917plus CTD & 285 (IFM-CEN) \\
Temperature 1: SBE-3-02/F & 1294 (IFM-CEN) \\
Conductivity 1: SBE-4-02/2 & 1106 (IFM-CEN) \\
Pressure 410K-105 & 50633 (IFM-CEN) \\
Temperature 2: SBE-3-02/F & 1717 (OGS) \\
Conductivity 2: SBE-4-02/2 & 3442 (OGS) \\
Altimeter PSA 916D & 885 (IFM-CEN) \\
Oxygen 1 SBE 43 & 1761 (IFM-CEN) \\
Oxygen 2 SBE 43 & 2513 (OGS) \\
\hline
\end{tabular}

the double sensors were correlated, and the salinity measurements were additionally corrected by comparison with the discrete salinity water samples to improve the level of precision. Since the corrections to the parameters were negligible, the data quality was excellent. Overall accuracies are within expected ranges: $0.002{ }^{\circ} \mathrm{C}$ for temperature and 0.003 for salinity.

Dissolved oxygen samples were analysed on board by means of the Winkler potentiometric method. The dissolved oxygen CTD data were treated in the same way as for temperature and salinity. A comparison between CTD oxygen sensors and the discrete water samples was carried out also for this parameter. The accuracy of the data reached approximately $2 \mu \mathrm{mol} \mathrm{kg}^{-1}$.

All procedures fit the guidelines of the GO-SHIP Repeat Hydrography Manual (McTaggart et al., 2010)

\subsection{Underway CTD}

Underway measurements of pressure, temperature and conductivity profiles were made with an Oceanscience UCTD system in order to increase the spatial resolution of the sur- 
Table 3. UCTD sensors used.

\begin{tabular}{lll}
\hline Probe 1 & Device type & Serial number (owner) \\
\hline 0068 & 90560 UCTD/SBE49 FastCat CTD & 70200068 (IFM-CEN) \\
0155 & 90745 UCTD/SBE 37 MicroCat & 70200155 (IFM-CEN) \\
0183 & 90745 UCTD/SBE 49 FastCat CTD & 70200183 (IFM-CEN) \\
\hline
\end{tabular}

vey, but without having to perform several additional timeconsuming CTD casts. Altogether, we took 378 casts (Fig. 1). Initially we used three probes ( $\mathrm{s} / \mathrm{n} 0068,0155$ and 0183 ), but after the loss of a probe right at the beginning of the cruise, we decided to use only the tow-yo (Ullman and Hebert, 2014) deployment procedure in the following, where no spooling on the probe's spindle was carried out. The sampling strategy included a sampling distance between UCTD casts of approximately $6 \mathrm{~nm}$ or about $1 \mathrm{~h}$ keeping a ship's speed of 6 knots. The ship reduced speed to 2-3 knots, while the probe was falling for a maximum of $480 \mathrm{~s}$. The ship enhanced speed again to 6 knots during the recovery of the probe. We reached maximum depths of around $850 \mathrm{~m}$, minimum depths of $500 \mathrm{~m}$. The average depth was approximately $650 \mathrm{~m}$. Specifications for the UCTD sensors are given in Table 3 .

The data are logged internally and are downloaded to a computer after recovery of the instrument. No processing is done internally. Since the probes are not georeferenced, ship navigation data were used. During processing one has to account for mainly two factors which cause inaccuracies: different probes show different offsets to the CTD, and the accuracy of results depends on the variable descent rate during deployment. For the correction of the offset we used data from CTD stations, as we carried out a UCTD measurement at each CTD position. Additionally, we run one CTD station with the remaining two UCTD probes installed at the CTD rosette. For each probe we determined the mean deviation from the UCTD with respect to the CTD casts and corrected all UCTD results accordingly. To account for the variable descent rate, we carried out the steps suggested by Ullman and Hebert (2014). Hence, we corrected for a descent-ratedependent alignment of temperature and conductivity, for the effect of viscous heating and for the conductivity cell thermal mass.

\subsection{Shipborne ADCP}

Underway current measurements were taken with a vesselmounted $75 \mathrm{kHz}$ Ocean Surveyor (ADCP) from RDI in narrow band mode covering approximately the top $600-800 \mathrm{~m}$ of the water column. The bin size was set to $8 \mathrm{~m}$. The instrument was controlled by computers using the conventional VMDAS software under a MS Windows system. Pinging was set as fast as possible. No interferences with other used acoustical instruments were observed. The ADCP data were post-processed with the software package ossi14 (ocean sur-

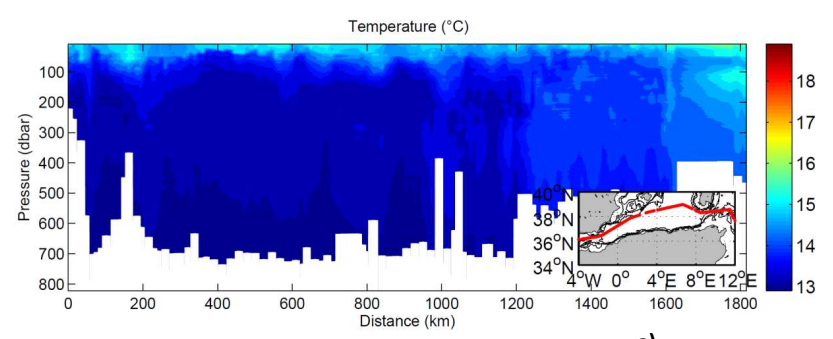

Salinity (psu)
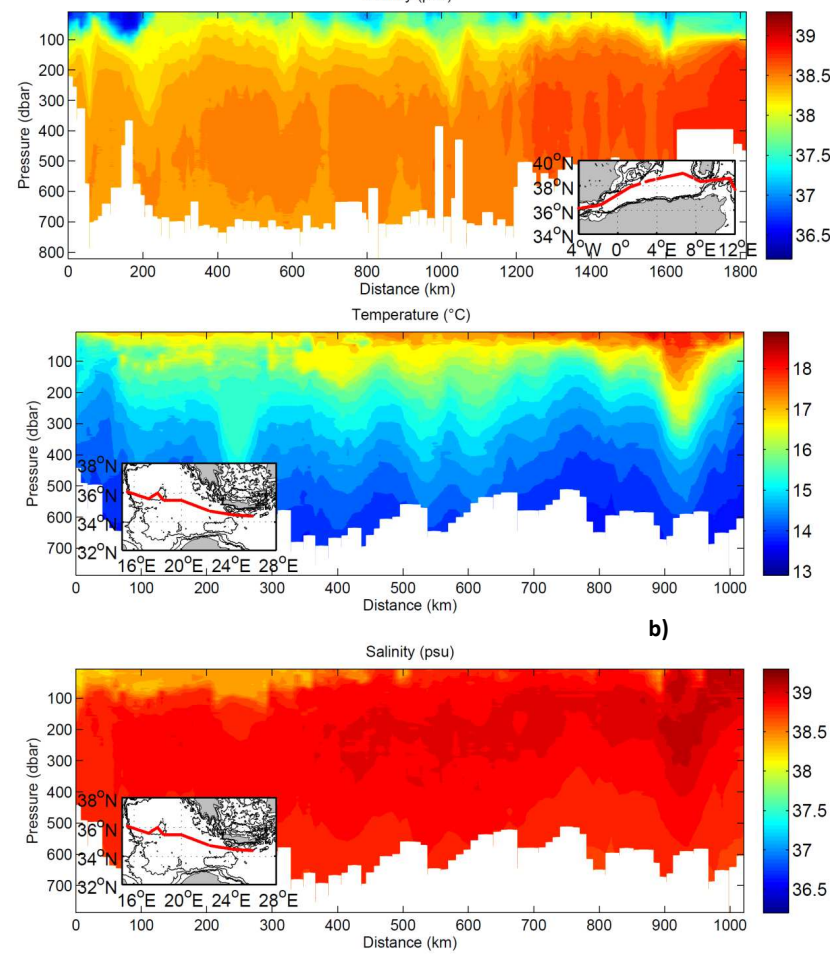

Figure 2. Temperature and salinity distribution along a west-east section through (a) the western Mediterranean Sea and (b) the eastern Mediterranean Sea. Data are recorded by an underway CTD. Inner panels show the location of UCTD stations. White areas: data are out of instrument range.

veyor sputum interpreter) developed by the Leibniz Institute of Marine Sciences (GEOMAR, Fischer, 2011), Kiel, which also corrects for the misalignment angle. The misalignment angle was calculated at approximately $-3.5^{\circ}$.

\section{Discussion and conclusion}

The temperature-salinity (TS) diagram (Fig. 3) gives an overview of the TS characteristics in the whole Mediterranean Sea during April 2014. The results are comparable to those we found already in April and June 2011 on cruises with RV Meteor and RV Poseidon (Hainbucher et al., 2014), and they highlight the differences which exist between the EMed and WMed. The horizontal distance between CTD stations was too coarse to consider the transects reliable, yet, the 


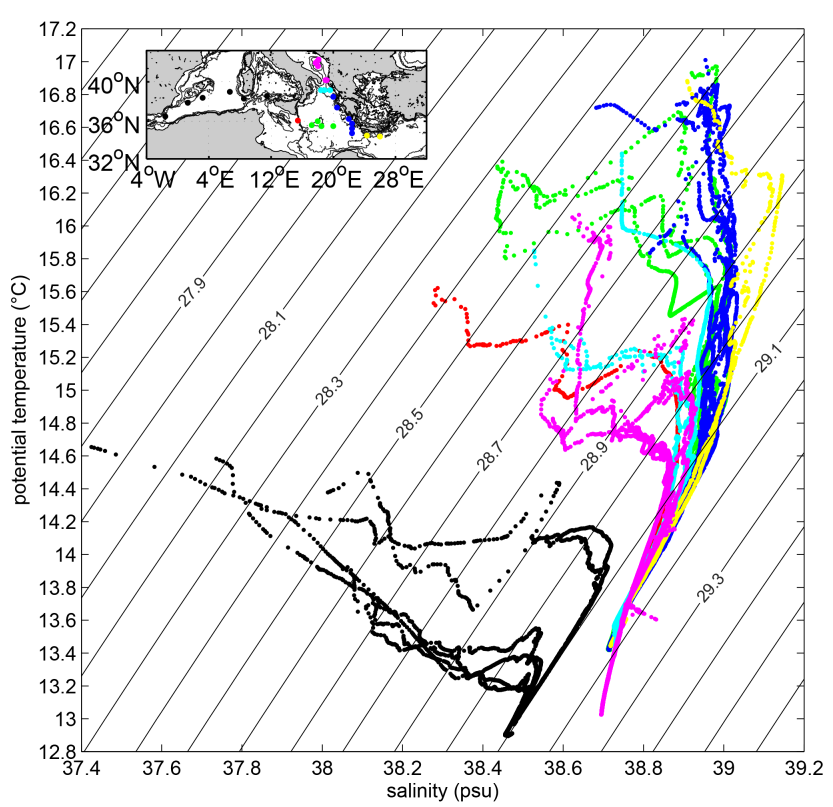

Figure 3. TS diagram determined by CTD data. The inner panel shows the location of CTD stations. The colours correspond to the colours of the profiles.

high resolution of UCTD (Fig. 2) and ADCP data (Fig. 4) show nicely the mesoscale variability in both basins during the cruise. Both Alboran gyres and high eddy activity along the section through the WMed can be identified. Some of these structures can be related to well-known features like the Almeria-Oran Gyre or the South-western Tyrrhenian Gyre (Pinardi et al., 2013). In the EMed we found a lot of mesoscale eddies along the track between Sicily and Crete. Presumably, we touched, amongst others, the Western Cretan Cyclonic Gyre and the Ierapetra Gyre (Pinardi et al., 2013). Hence, some of the positions of the gyres that we found have confirmed those already present in the literature by observations or results of models. But not all of the gyres can be related to well-known features. We conclude from this fact that a lot of the gyres are non-permanent and that even the location of the permanent eddies are subject to high spatial variability. This has to be concretized and proofed further. The tool for the investigation of such highly variable phenomena was up to now numerical models, but with such UCTD measurements it is possible to resolve the structures with a reasonable effort in terms of time and money.

The salinity distribution (Fig. 2) furthermore reflects the spatial development of LIW from east to west. The LIW signal is stronger in the EMed than in the WMed and can be identified by the salinity maximum in the $100-600 \mathrm{~m}$ depth layer.
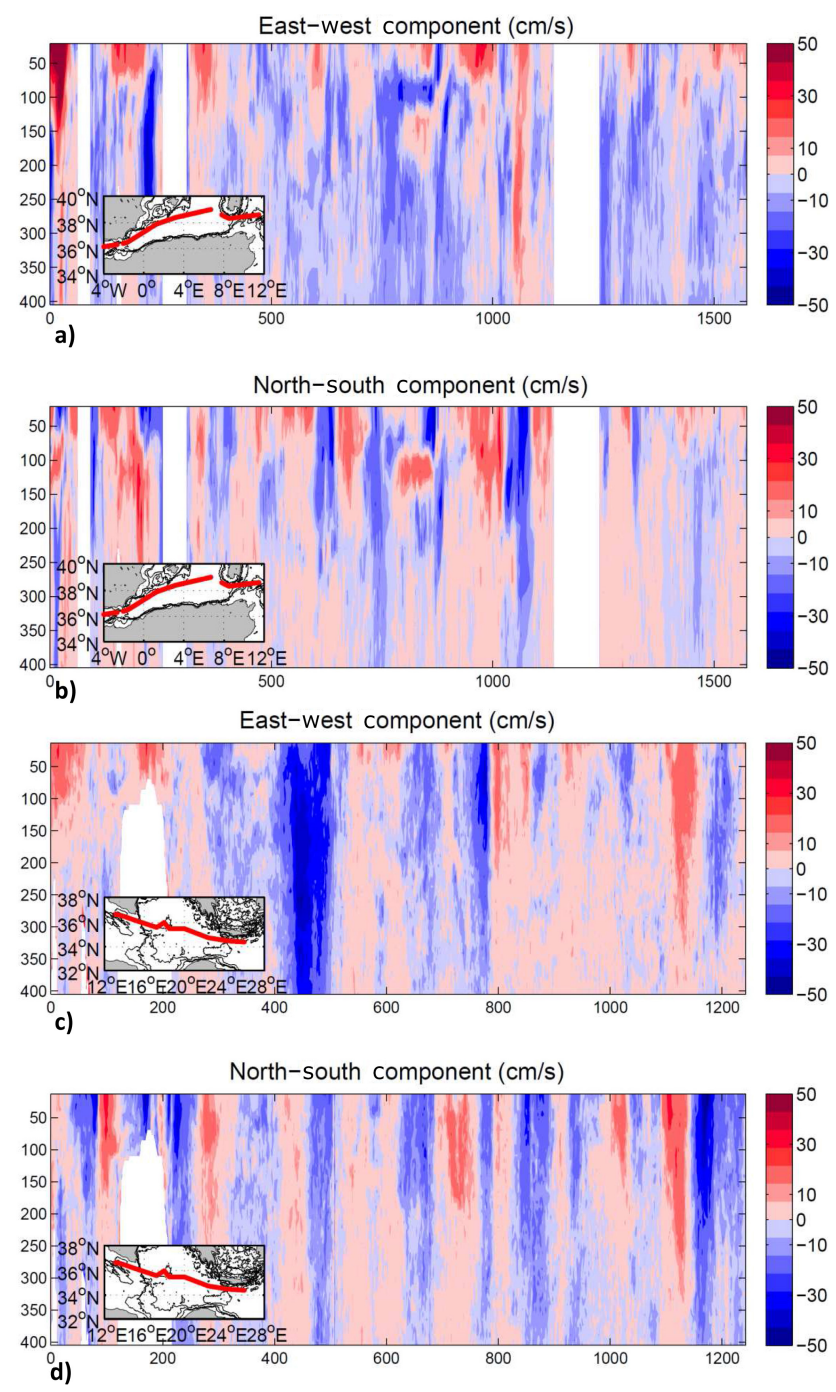

Figure 4. Velocity distribution of the upper $400 \mathrm{~m}$ of the water column along a west-east section through (a) the western Mediterranean Sea and (b) the eastern Mediterranean Sea. Data are recorded by a shipborne ADCP. Shown are the east-west and north-south velocity component, respectively. Inner panels indicate the location of the ship track. White areas: no data are available. $x$ axes: east-west distance $(\mathrm{km}), y$ axes: depth (dbar).

\section{Data access}

Data are published in the information system PANGAEA; doi:10.1594/PANGAEA.838923 for CTD data, doi:10.1594/PANGAEA.838924 for UCTD data and doi:10.1594/PANGAEA.838934 for ADCP data.

Acknowledgements. We would like to thank Captain Matthias Günther, his officers and the crew of RV Poseidon for the support of our scientific programme and Norbert Verch for post-processing the CTD data. 
The ship time of RV Poseidon and the transport of equipment were provided by the University of Hamburg. The financial support for the journey of scientists and the facilities of the cruise, like consumption (for technical equipment), were provided by the project of the "Deutsche Forschungsgemeinschaft" DFG Qu46/16-1. The Italian Ministry of Education, University and Research (MIUR) supported parts of this research under the RITMARE (Ricerca ITaliana per il MARE) national project. We gratefully acknowledge their support.

Edited by: G. M. R. Manzella

\section{References}

Bacon, S., Culkin, F., Higg, N., and Ridout, P.: IAPSO Standard Seawater: Definition of the Uncertainty in the Calibration Procedure, and Stability of Recent Batches, J. Atmos. Ocean. Tech., 24, 1785-1799, 2007.

Cardin, V., Civitarese, G., Hainbucher, D., Bensi, M., and Rubino, A.: Thermohaline properties in the Eastern Mediterranean in the last three decades: is the basin returning to the pre-EMT situation?, Ocean Sci., 11, 53-66, doi:10.5194/os-11-53-2015, 2015.

CIESM: Designing Med-SHIP: a Program for repeated oceanographic surveys, No 43, in: CIESM Workshop Monographs, edited by: Briand, F., 164 pp., Monaco, 2012.

Fischer, T.: Diapycnal diffusivity and transport of matter in the open ocean estimated from underway acoustic profiling and microstructure profiling, $\mathrm{PhD}$ thesis, Leibniz Institute of Marine Sciences (GEOMAR), University of Kiel, Germany, 105 pp., 2011.

Gačić, M., Civitarese, G., Eusebi Borzelli, G. L., Kovačević, V., Poulain, P.-M., Theocharis, A., Menna, M., Catucci, A., and Zarokanellos, N.: On the relationship between the decadal oscillations of the Northern Ionian Sea and the salinity distributions in the Eastern Mediterranean, J. Geophys. Res., 116, C12002, doi:10.1029/2011JC007280, 2011.

Garrett, C., Outbridge, R., and Thomson, K.: Interannual variability in Mediterrancan heat and buoyancy fluxes, J. Climate, 6, 900910, 1993.

Hainbucher, D., Rubino, A., Cardin, V., Tanhua, T., Schroeder, K., and Bensi, M.: Hydrographic situation during cruise M84/3 and P414 (spring 2011) in the Mediterranean Sea, Ocean Sci., 10, 669-682, doi:10.5194/os-10-669-2014, 2014.

Hamad, N., Millot, C., and Taupier-Letage, I.: A new hypothesis about surface circulation in the eastern basin of the Mediterranean Sea, Prog. Oceanogr., 66, 287-298, 2005.

Hecht, A., Pinardi, N., and Robinson, A. R.: Currents, water masses, eddies and jets in the Mediterranean Levantine basin, J. Phys. Oceanogr., 18, 1320-1353, 1988.

Klein, B., Roether, W., Manca, B., and Theocharis, A.: The evolution of the Eastern Mediterranean Climatic transient during the last decade: the tracer viewpoint, in: The Eastern Mediterranean Transient, edited by: Briand, F., CIESM Workshop Series, Vol. 10, CIESM, Monaco, 21-25, 2010.

Lascaratos, A., Roether, W., Nittis, K., and Klein, B.: Recent changes in deep water formation and spreading in the eastern Mediterranean Sea: a review, Prog. Oceanogr., 44, 5-36, 1999.
Leaman, K. D. and Schott, F.: Hydrographic structure of the convection regime in the Golfe du Lion, J. Phys. Oceanogr., 23, 575598, 1991.

Malanotte-Rizzoli, P., Manca, B. B., Ribera d'Alcala, M., Teocharis, A., Bergamasco, A., Bregant, D., Budillon, G., Civitarese, G., Georgopoulos, D., Michelato, A., Sansone, E., Scarazzato, P., and Souvermezoglou, E.: A synthesis of the Ionian Sea hydrography, circulation and water mass pathways during POEM-Phase I, Prog. Oceanogr., 39, 153-204, 1997.

Malanotte-Rizzoli, P., Manca, B. B., Ribera d'Alcala, M., Theocharis, A., Brenner, S., Budillon, G., and Ozsoy, E.: The Eastern Mediterranean in the 80s and in the 90s: the big transition in the intermediate and deep circulations, Dynamics Atmos. Oceans, 29, 365-395, 1999.

McTaggart, K. E., Johnson, G. C., Johnson, M. C., Delahoyde, F. M., and Swift, J. H.: Notes On CTD/O 2 Data Acquisition And Processing Using Sea-Bird Hardware And Software (as available), in: The GO-SHIP Repeat Hydrography Manual: A Collection of Expert Reports and Guidelines, IOCCP Report No. 15, ICPO Publication Series No. 134, Version 1, 2010.

Millot, C., Candela, J., Fuda, J. L., and Tber, Y.: Large warming and salinification of the Mediterranean outflow due to changes in its composition, Deep-Sea Res. Pt. I, 53, 656-666, 2006.

Pettenuzzo, D., Large, W. G., and Pinardi, N.: On the corrections of era-40 surface flux products consistent with the Mediterranean heat and water budgets and the connection between basin surface total heat flux and nao, J. Geophys. Res.-Oceans, 108, C06022, doi:10.1029-2009JC005631, 2010.

Pinardi, N., Zavatarelli, M., Adani, M., Coppini, G., Fratianni, C., Oddo, P., Simoncelli, S., Tonani, M., Lyubartsev, V., Dobricic, S., and Bonaduce, A.: Mediterranean Sea large-scale low-frequency ocean variability and water mass formation rates from 1987 to 2007: A retrospective analysis, Prog. Oceanogr., 132, 318-332, doi:10.1016/j.pocean.2013.11.003, 2013.

Robinson, A. R., Wayne, G. L., Theocharis, A., and Lascaratos, A.: Mediterranean Sea Circulation, in: Encyclopedia of Ocean Sciences, Academic Press, 1689-1705, doi:10.1006/rwos.2001.0376, 2001.

Roether, W., Klein, B., Manca, B. B., Theocharis, A., and Kioroglou, S.: Transient Eastern Mediterranean deep waters in response to the massive dense-water output of the Aegean Sea in the 1990s, Prog. Oceanogr., 74, 540-571, 2007.

Roether, W., Klein, B., and Hainbucher, D.: The Eastern Mediterranean Transient: Evidence for Similar Events Previously?, in: The Mediterranean Sea: Temporal Variability and Spatial Patterns, edited by: Borzelli, G. L. E., AGU monographs, 2013.

Rubino, A. and Hainbucher, D.: A large abrupt change in the abyssal water masses of the eastern Mediterranean, Geophys. Res. Lett., 34, L23607, doi:10.1029/2007GL031737, 2007.

Said, M. H., Gerges, M. A., Maiyza, I. A., Hussein, M. A., and Radwan, A. A.: Changes in Atlantic Water characteristics in the south-eastern Mediterranean Sea as a result of natural and anthropogenic avtivities, Oceanologia, 53, 81-95, 2011.

Schroeder, K., Gasparini, G. P., Tangherlini, M., and Astraldi, M.: Deep and intermediate water in the western Mediterranean under the influence of the Eastern Mediterranean Transient, Geophys. Res. Lett., 33, L21607, doi:10.1029/2006GL027121, 2006.

Schroeder, K., Ribotti, A., Borghini, M., Sorgente, R., Perilli, A., and Gasparini, G. P.: An extensive western Mediterranean deep 
water renewal between 2004 and 2006, Geophys. Res. Lett., 35, L18605, doi:10.1029/2008GL035146, 2008.

Schroeder, K., Garcìa-Lafuente, J., Josey, S. A., Artale, V., Buongiorno Nardelli, B., Carrillo, A., Gacic, M., Gasparini, G. P., Herrmann, M., Lionello, P., Ludwig, W., Millot, C., Özsoy, E., Pisacane, G., Sánchez-Garrido, J. C., Sannino, G., Santoleri, R., Somot, S., Struglia, M., Stanev, E., Taupier-Letage, I., Tsimplis, M. N., Vargas-Yáñez, M., Zervakis, V., and Zodiatis, G.: Circulation of the Mediterranean Sea and its variability, in: The Climate of the Mediterranean Region: From the Past to the Future, edited by: Lionello, P., Elsevier Insights, Amsterdam, 2012.

Schroeder, K., Millot, C., Bengara, L., Ben Ismail, S., Bensi, M., Borghini, M., Budillon, G., Cardin, V., Coppola, L., Curtil, C., Drago, A., El Moumni, B., Font, J., Fuda, J. L., García-Lafuente, J., Gasparini, G. P., Kontoyiannis, H., Lefevre, D., Puig, P., Raimbault, P., Rougier, G., Salat, J., Sammari, C., Sánchez Garrido, J. C., Sanchez-Roman, A., Sparnocchia, S., Tamburini, C., Taupier-Letage, I., Theocharis, A., Vargas-Yáñez, M., and Vetrano, A.: Long-term monitoring programme of the hydrological variability in the Mediterranean Sea: a first overview of the HYDROCHANGES network, Ocean Sci., 9, 301-324, doi:10.5194/os-9-301-2013, 2013.
Tanhua, T., Hainbucher, D., Cardin, V., Álvarez, M., Civitarese, G., McNichol, A. P., and Key, R. M.: Repeat hydrography in the Mediterranean Sea, data from the Meteor cruise 84/3 in 2011, Earth Syst. Sci. Data, 5, 289-294, doi:10.5194/essd-5-289-2013, 2013.

Ullman, D. S. and Hebert, D.: Processing of Underway CTD data, J. Atmos. Ocean. Techn., 31, 984-998, doi:10.1175/JTECH-D13-00200.1, 2014. 